\title{
PERKEMBANGAN INFRASTRUKTUR DAN PERUBAHAN HIRARKI KOTA (STUDI KASUS KABUPATEN/KOTA DI JAWA TENGAH BERDASAR TAHUN SENSUS PENDUDUK 1990, 2000, 2010)
}

\author{
Shandy Jannifer Matitaputty \\ Anita Primadani \\ Universitas Katolik Soegijapranata \\ deta.matitaputty@gmail.com
}

\begin{abstract}
The population growth of a region and its adjacent areas will create new needs. These needs are created by the advancement of culture and the increasing complexity of population activity. The emerging needs give rise to the consequent increase in infrastructure provision. The availability of adequate municipal infrastructure is believed to be one of the factors driving the city's development as reflected in the hierarchy of the city.

Central Java province has 35 districts adjacent and interact with each other. Each of these districts has a population that changes with time. City residents are considered as a society that has high economic activity that will spur revenue growth region.

The development of urban infrastructure is likely to result in the development of the urban population which ultimately increases the hierarchy of the city. This study intends to see whether infrastructure developments in districts in Central Java will result in an increase in urban population in the region which further impacts on changes in the hierarchy of cities. The results show that population growth has resulted in increased population activity, transportation and technology systems along with the times. In the long run, this leads to a change of urban hierarchy. This is also because the adjacent districts will be connected and influenced. Changes in the hierarchy of cities that occurred in the years 1990-2010 in the district in Central Java province showed that the highest hierarchy position occupied by Semarang City. This is driven by the rapid development of infrastructure and technology in Semarang City. The rapid development of infrastructure and technology of Semarang City become a big enough attraction for residents of the surrounding area to move to Semarang City.
\end{abstract}

Keywords: City Hierarchy, Urban Infrastructure, Population Growth of Central Java 


\section{PENDAHULUAN}

Kota secara geografis merupakan konsentrasi penduduk dan kegiatan usahanya pada lokasi yang strategis secara ekonomi, sosial maupun fisik. Seiring dengan perkembangan waktu, jumlah penduduk turut mengalami perkembangan sehingga infrastruktur Kota juga berkembang mengikuti perkembangan kebutuhan penduduk.

Hirarki Kota secara umum dapat dimengerti sebagai peringkat Kota berdasar suatu faktor penentu, misalnya jumlah penduduk dan komposisi penggunaan lahan. Hammond (dalam Rafeal Murtomo: 1992) menjelaskan bahwa hirarki Kota adalah suatu urutan peringkat Kota atas dasar ukuran peranan dan fungsinya dalam kaitannya dengan kota-kota lainnya, dengan mengasumsikan pertumbuhan wilayah kota tidak terjadi secara acak namun tumbuh dalam urutan yang logis sehingga baik ukuran maupun fungsinya berkaitan dengan keteraturan menyeluruh. Richardson (Paul Sitohang: 2014) menjelaskan bahwa struktur hirarkis dari pusat pusat nodal akan tercermin tidak hanya dalam tata ruangnya saja tetapi juga dalam besar relatifnya. Sistim pusat pusat perkotaan dapat dikategorikan secara vertikal dan sesuai dengan itu pusat-pusat disusun urut menurut besarnya jumlah penduduk, hal mana menghasilkan suatu hirarki besarnya perkotaan.

Terdapat beberapa metode penetapan orde perkotaan. Metode rank-size rule jumlah penduduk kota orde ke-n adalah $1 / \mathrm{n}$ jumlah penduduk kota orde tertinggi seperti dirumuskan dalam persamaan berikut:

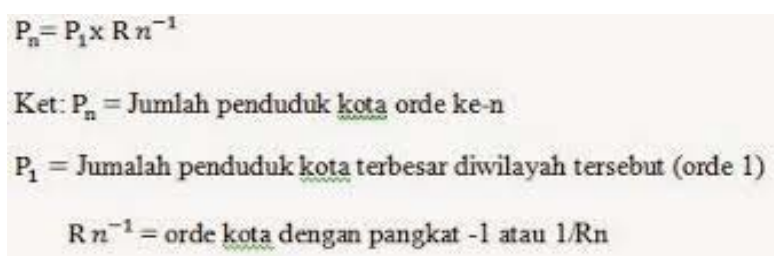

Metode lainnya dikenal dengan nama metode zipf, metode ini dikemukakan oleh Auerbach dan Singer namun lebih dipopulerkan oleh zipf, metode ini mengemukakan bahwa ukuran distribusi aktivitas ekonomi dari suatu kota akan mengikuti distribusi Pareto, sekaligus juga memiliki bentuk parameter tertentu. Hukum zipf inilah yang menjadi dasar dari Rank Size Rule, suatau persaman yang digunakan untuk melihat proporsi distribusi aktivitas ekonomi perkotaan (Paul Sitohang: 2014). Rumus metode zipf adalah sebagai berikut:

$$
\mathrm{P}_{n}=\frac{\mathrm{P}_{1}}{\mathrm{n}^{q}}
$$

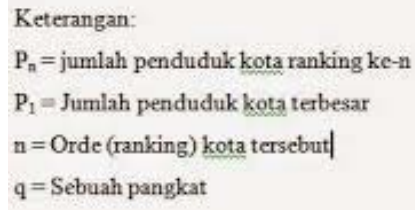

Dengan mengetahui hirarki suatu kota dapat dibuat perencanaan yang lebih tepat sasaran dalam penyediaan fasilitas dan pelayanan publik. Dilihat secara fungsional kota memiliki dua fungsi yaitu lingkup internal dan lingkup eksternal. Di lingkup internal kota berfungsi untuk melayani kegiatan sosial ekonomi bagi penduduknya seperti penyedia lapangan kerja, prasarana dan sarana kota. Di lingkup eksternal sebuah kota berfungsi untuk melayani wilayahwilayah disekitarnya (Ambardi, 2002). Dalam kaitannya dengan hirarki, Rondinelli (1983) mengungkapkan bahwa hirarki atau tingkatan kota akan mempengaruhi fungsinya. Melihat cukup pentingnya perubahan hirarki kota, tulisan ini bermaksud melihat perubahan hirarki kota di Jawa Tengah dalam selang waktu tiga periode sensus penduduk terkni yakni sensus tahun 1990, tahun 2000 dan 2010 serta untuk melihat apakah pertumbuhan penduduk mengakibatkan perkembangan infrastuktur yang selanjutnya berdampak pada perubahan hirarki kota Kabupaten/ Kota di Jawa Tengah 


\section{TINJAUAN PUSTAKA}

\section{Kota}

Kota merupakan tempat dimana konsentrasi penduduk lebih padat dari wilayah sekitarnya karena terjadinya pemusatan kegiatan fungsional yang berkaitan dengan kegiatan atau aktivitas penduduknya. Pengertian "kota" sebagaimana yang diterapkan di Indonesia merupakan satuan administrasi negara di bawah propinsi dan diatas kecamatan. Selain kota, di Indonesia pembagian wilayah administrasi setelah propinsi adalah kabupaten. Kabupaten maupun kota merupakan daerah otonom yang diberi wewenang mengatur dan mengurus urusan pemerintahannya sendiri.

Menurut Bintarto (1977), kota adalah suatu sistem jaringan kehidupan manusia dengan kepadatan penduduk yang tinggi, strata sosial ekonomi yang heterogen, dan corak kehidupan yang maternalistik. Kawasan perkotaan merupakan kawasan yang mempunyai kegiatan utama bukan pertanian dengan susunan fungsi kawasan sebagai tempat pemukiman, pemusatan dan distribusi pelayanan jasa pemerintahan, pelayanan sosial, dan kegiatan ekonomi. Kawasan perkotaan dapat dikatakan juga sebagai aglomerasi kota-kota dengan daerah sekitarnya yang memiliki sifat kekotaan, dapat melebihi batas politik/administrasi dari kota yang bersangkutan.

Perkembangan suatu kota dipengaruhi oleh keterkaitan kota tersebut dengan kota-kota atau wilayah di sekitarnya baik dalam maupun luar negeri. Keterkaitan tersebut terwujud dalam bentuk pergerakan barang, jasa, manusia, uang, dan investasi. Keterkaitan ini memegang peran yang penting dalam pembentukan pola dan struktur pada suatu kota.

\section{Sistem Perkotaan}

Sistem kota-kota terjadi karena adanya keterkaitan antara satu kota dengan kota lainnya, melalui jejaring atau aliran antara kota-kota tersebut (simpul kota). Setiap kota memiliki kekuatan berbeda-beda antara satu dan lainnya.
Kekuatan yang dimaksud adalah keadaan ekonomi, kualitas penduduk serta distribusi penduduk yang terjadi pada kota tersebut. Suatu kota memiliki kekuatan atau potensi yang ditentukan oleh beberapa faktor, yaitu tersedianya infrastruktur, faktor lokasi dari kota tersebut, karakteristik penduduk yang dimiliki suatu kota.

Fungsi dan peran kota dalam suatu kawasan dapat teridentifikasi berdasarkan besar kecilnya kekuatan kota yang dimiliki. Beberapa kota yang saling berkaitan secara fungsional, dapat digambarkan oleh orientasi pemasaran geografis. Pada tingkat nasional maupun tingkat regional, setiap sistem kota berorientasi pada satu simpul utama, yang pada akhirnya menjadi bagian dari suatu sistem perkotaan yang terintegrasi secara nasional. Proses pembentukan suatu sistem perkotaan sangat sering terjadi pada sepanjang jalur transportasi utama dan jaringan komunikasi yang menghubungkan simpul utama.

Sistem perkotaan merupakan aglomerasi kota dengan wilayah sekitarnya yang masih memiliki sifat kekotaan. Sistem perkotaan tidak hanya terdiri dari himpunan objek secara fisik (dalam hal ini pemukiman perkotaan) melainkan juga aliran dan keterhubungan yang bertujuan saling mengikat. Aliran dapat berupa pergerakan orang, barang, faktor produksi, ide, informasi, dan inovasi.

Faktor-faktor yang mempengaruhi terbentuknya sistem perkotaan meliputi

Aglomerasi dari kota-kota ukuran besar, sedang hingga kecil, terjadi pertambahan penduduk dan perluasan wilayah yang sangat cepat, terutama pada kota-kota besar sepanjang jalur transportasi arteri; Peningkatan dan perbaikan di bidang transportasi dan telekomunikasi yang dapat meningkatkan pergerakan penduduk dan komoditi, baik dalam lingkup wilayah maupun antar wilayah, sehingga hal tersebut akan mendorong terbentuknya suatu sistem perkotaan. 
Interaksi dalam sistem perkotaan memiliki beberapa peran yang penting, antara lain dapat mewujudkan interaksi spasial, terjadinya diferensiasi dan spesialisasi dalam sistem perkotaan, sebagai wahana untuk pengorganisasian kegiatan dalam ruang, memfasilitasi dan menyalurkan perubahanperubahan dari satu simpul ke simpul lainnya dalam sistem perkotaan tersebut

\section{Fungsi dan Peran Kota}

Kota yang telah berkembang mempunyai fungsi yang lebih luas, antara lain:

1. Sebagai pusat produksi

2. Sebagai pusat perdagangan

3. Sebagai pusat pemukiman dan kegiatan penduduk

4. Sebagai pusat pemerintahan

5. Sebagai pusat kebudayaan

Selain itu kota juga memiliki fungsi khusus, dimana dominasi kegiatan fungsional suatu kota dapat dicirikan oleh kegiatan ekonomi pada kota tersebut. Peran yang dimiliki oleh suatu kota dalam lingkup wilayah, akan dapat dilihat dari aspek skala pelayanan kota tersebut dalam wilayah yang lebih luas.

\section{Pembangunan Kota}

Menurut Sadono (1985), pembangunan ekonomi perkotaan mempunyai pengertian sebagai proses yang menyebabkan pendapatan perkapita suatu masyarakat kota meningkat dalam jangka panjang. Tantangan pembangunan ekonomi perkotaan saat ini terletak pada kemampuan sistem ekonomi untuk mengembangkan ekonomi dan membagikan sumber daya perkotaan yang merata atau "pertumbuhan dengan pemerataan", dengan kata lain mengarahkan pembangunan ekonomi yang mampu menciptakan keseimbangan regional. Hal ini memerlukan keterpaduan kebijaksanaan pembangunan ekonomi dan kebijaksanaan pengembangan tata ruang perkotaan dalam skala regional.

Beberapa masalah kebijaksanaan perkotaan yang dihadapi antara lain:

a. Penyebaran penduduk, karena hubungan penduduk dengan sumber daya lainnya perlu diselaraskan, maka perhatian harus ditujukan pada masalah yang berkaitan dengan penyebaran penduduk.

b. Migrasi dari desa ke kota; kemampuan mengendalikan atau mengubah arah, laju dan ciri-ciri arus perpindahan penduduk sangat penting karena dampaknya pada daerah asal, daerah tujuan dan pertumbuhan ekonomi nasional.

c. Jenjang perkotaan; besaran dan penyebaran tata ruang kota menentukan efisiensinya dalam menjalankan perannya dalam pembangunan ekonomi kota.

d. Ukuran dan efisiensi kota; ukuran optimum kota adalah fungsi lokasi dan perannya dalam mengembangkan sistem management kota.

e. Perluasan kota; pertumbuhan kota yang cepat serta proses pemusatan penduduk mengakibatkan terlampauinya beban optimum sarana dan prasarana kota. Tekanan yang besar mengakibatkan meluasnya pengaruh fungsi kota ke wilayah sekitar.

\section{Sistem Hirarki Kota}

Sistem transport yang efisien memungkinkan masyarakat mengatasi masalah jarak serta struktur kegiatan yang terpusat. Kota merupakan pusat pertumbuhan dan secara fungsional merupakan tempat terkonsentrasinya manusia dengan segala aktifitasnya serta sarana dan prasarana penunjang sehingga mampu mendorong berkembangnya aktivitas perekonomian baik untuk diri sendiri maupun ke daerah hinterland. (Rusmasyah: 2006) 
Menurut Tarigan (2004) pusat pertumbuhan bersifat mendorong pertumbuhan daerah belakangnya. Proses perkembangan dan perluasan kota yang disertai dengan perubahan struktur tata guna lahan sebagian besar disebabkan oleh adanya gaya sentrifugal dan gaya sentripetal.

Pengaruh pusat kota terhadap wilayah pinggirannya sangat dipengaruhi oleh jarak kedua kota tersebut dan jumlah penduduknya (model gravity yang dikenal dengan teori Rielly). Banyaknya fasilitas perkotaan cenderung berkaitan dengan besarnya kota tersebut dan membentuk suatu hirarki berdasarkan jarak dan ambang batas penduduk. Sehingga pembagian hirarki fasilitas pelayanan tersebut, mengakibatkan suatu kota (dengan hirarki pelayanan paling tinggi) secara alami memiliki potensi daya tarik yang besar dan berpengaruh besar bagi daerah-daerah yang kekuatannya lebih kecil, dimana kota tersebut mempunyai kemampuan menarik potensi, sumber daya dari daerah lain dan kota dibawahnya.

Kota memiliki faktor-faktor pembeda jika ditinjau dari jumlah penduduk, fasilitas sarana dan prasarana, dan tingkat aksesbilitas kota tersebut ke kota terdekat dan hal ini dapat dijadikan dasar bagi penilaian penentuan orde kota (Tarigan, 2004).Dengan mengetahui ranking kota, banyak keuntungan yang dapat diperoleh dalam perencanaan penyediaan fasilitas kota yang berguna dalam penyusunan struktur ruang wilayah. Analisis yang mengaitkannya dengan sistem transportasi (jaringan dan mode) serta lokasi dalam kegiatan besar yang terkonsentrasi dapat menciptakan arus pergerakan orang, barang dan jasa.

Dalam penyusunan program yang berkaitan dengan jenis dan besarnya fasilitas yang dibutuhkan, orde kota sangat dibutuhkan agar terdapat keselarasan anatara ketersediaan dan kebutuhan termasuk di dalamnya peramalan, monitoring serta bahan masukkan dalam perencanaan kota.

Dalam Rusmansyah (2006), Rondinelli (1983: 120-170) mengungkapkan hirarki atau tingkatan kota akan mempengaruhi fungsi suatu kota. Kota-kota menengah dan kecil mempunyai fungsi yang dapat digolongkan ke dalam delapan bagian, yaitu : (1) Pusat pelayanan umum dan sosial; (2) Pusat komersial dan pelayanan jasa; (3) Pusat pemasaran dan perdagangan regional; (4) Pusat penyediaan dan pemrosesan produkproduk pertanian; (5) Pusat industri kecil; (6) Pusat transportasi dan komunikasi regional; (7) Pusat penarik migrasi dari pedesaan dan menjadi sumber pendapatan bagi daerah pedesaan; (8) Pusat transformasi sosial.

MenurutJohnFreedmandan CleydeWever dalam Rusdiansyah (2006) mengungkapkan faktor skala ekonomi yang dapat menerapkan skala besar dan optimal merupakan faktor yang dapat menyebabkan terkonsentrasinya kegiatan ekonomi ke wilayah perkotaan. Rencana Hirarki Perkotaan ditetapkan dengan menggunakan ketentuan ukuran besaran kota dengan menggunakan indikator jumlah penduduk yang terapat dalam Lampiran V Keputusan Menteri Pemukiman dan Prasarana Wilayah No. 327/ KTPS/M/2002, sebagai berikut :

1. Kawasan Perkotaan Metropolitan, yaitu kawasan perkotaan dengan jumlah penduduk yang dilayani lebih besar dari 1.000.000 jiwa

2. Kawasan Perkotaan Besar, yaitu kawasan perkotaan dengan jumlah penduduk yang dilayani lebih besar dari 500.000 jiwa

3. Kawasan Perkotaan Sedang, yaitu kawasan perkotaan dengan jumlah penduduk yang dilayani sebesar 100.001 hingga 500.000 jiwa

4. Kawasan Perkotaan Kecil, yaitu kawasan perkotaan dengan jumlah penduduk yang dilayani sebesar 10.000 hingga 100.000 jiwa 


\section{Kerangka Pemikiran}

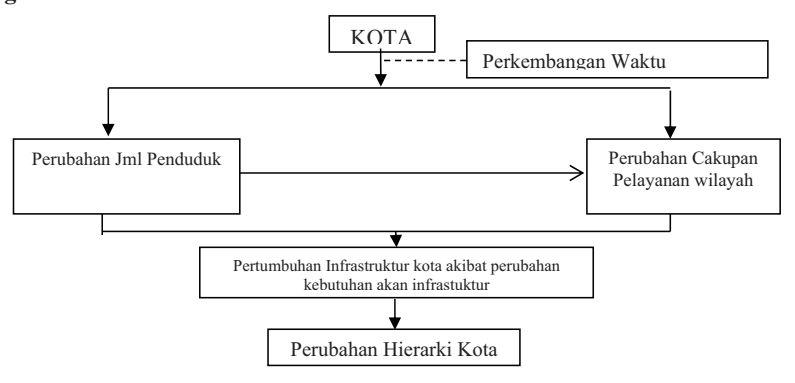

Gambar 1

Kerangka Pemikiran

\section{METODE PENELITIAN}

Penelitian ini, merupakan penelitian deskriptif kualitatif. Penelitian ini mencoba menganalisis fenomena-fenomena sosial yang dilakukan dengan mengkaji informasi dari permasalahan yang ada pada objek penelitian dan dihubungkan dengan pemecahan permasalahan yang ditinjau dari kajian teoritis maupun empiris untuk melihat perubahan hirarki kota di Jawa Tengah.

Metoda kualitatif yang digunakan dilengkapi dengan metoda kuantitatif yang didapatkan dari kegiatan pengumpulan data sekunder, yang bersumber dari data-data terbitan Biro Pusat Statistik (BPS), BKKBN, maupun jurnal- jurnal dan bacaan terkait.

\section{Tehnik Perhitungan Hirarki Kota}

Tehnik perhitungan hirarki kota menggunakan indikator utama rasio jumlah penduduk perkotaan, yang kemudian dikelompokkan dalam lima orde. Penentuan orde ditetapkan dengan cara rasio dari kabupaten/ kota tertinggi dikurangi rasio kabupaten/kota terendah dibagi dengan jumlah kelas. Hasil ini merupakan interval kelas dan dengan demikian, skor setiap kabuapeten/ kota dapat dimasukkan ke dalam kelompok-kelompok kelas tersebut. Selanjutnya orde/hirarki kabupaten/kota dapat diperoleh hasilnya.

\section{Tehnik Perhitungan Cakupan Wilayah/ Batasan Pengaruh Suatu Wilayah}

Tehnik perhitungan batasan pengaruh suatu wilayah dalam penelitian ini menggunakan analisis Relly's Law of Retail Grafitaion. Rumus dari metode ini:

$$
S_{b, a}=\frac{D_{b a}}{\left(1+\sqrt{ } P_{b} / P_{a}\right)}
$$

Dengan:

$\mathrm{S}_{\mathrm{b}, \mathrm{a}}=$ Wilayah pengaruh a terhadap $\mathrm{b}$

$\mathrm{D}_{\mathrm{ba}}=$ Jarak kota a ke kota $\mathrm{b}$

$\mathrm{P} \quad=$ Jumlah Penduduk

\section{ANALISIS DAN PEMBAHASAN}

\section{Gambaran Umum Provinsi Jawa Tengah}

Provinsi Jawa Tengah merupakan salah satu provinsi di Indonesia yang letaknya cukup strategis karena berada di daratan padat Pulau Jawa, diapit oleh dua Provinsi besar Jawa Barat dan Jawa Timur, dan satu Daerah Istimewa Yogyakarta.

Luas wilayah Provinsi Jawa Tengah sebesar 32.544,12 Hektar (Ha), terdiri dari 29 Kabupaten dan 6 Kota dengan 565 Kecamatan serta 8.568 desa/kelurahan. Daerah yang terluas adalah Kabupaten Cilacap dengan luas 2.13.851 Ha atau sekitar 6,57 \% dari luas total Provinsi Jawa Tengah, sedangkan Kota Magelang merupakan daerah yang memiliki wilayah paling kecil yaitu seluas $1.812 \mathrm{Ha}$.

Topografi Provinsi Jawa Tengah terdiri dari wilayah daratan sebagai berikut :

- Ketinggian antara $0-100 \mathrm{~m}$ dari permukaan laut yang memanjang di sepanjang pantai utara dan selatan seluas 53,3\%,

- Ketinggian 100 - 500 m dari permukaan laut yang memanjang pada bagian tengah pulau seluas $27,4 \%$, 
- Ketinggian $500-1.000 \mathrm{~m}$ dari permukaan laut seluas $14,7 \%$,

- Ketinggian di atas $1.000 \mathrm{~m}$ dari permukaan laut seluas $4,6 \%$.

Dalam hal administrasi pemerintahan, Propinsi Jawa Tengah terbagi dalam 29 Kabupaten dan 6 kota. Administrasi pemerintahan kabupaten dan kota ini terdiri dari 544 kecamatan, dan 8.490 desa/kelurahan. Adapun kabupaten/ kota di Propinsi Jawa Tengah adalah sebagai berikut: Kabupaten Cilacap, Kabupaten Banyumas, Kabupaten Purbalingga, Kabupaten Banjarnegara, Kabupaten Kebumen, Kabupaten Purworejo, Kabupaten Wonoboso, Kabupaten Magelang, Kabupaten Boyolali, Kabupaten Klaten, Kabupaten Sukoharjo, Kabupaten Wonogiri, Kabupaten Karanganyar, Kabupaten Sragen, Kabupaten Grobogan, Kabupaten Blora, Kabupaten Rembang, Kabupaten Pati, Kabupaten Kudus, Kabupaten Jepara, Kabupaten Demak, Kabupaten Semarang, Kabupaten Temanggung, Kabupaten Kendal, Kabupaten Batang, Kabupaten Pekalongan, Kabupaten Pemalang, Kabupaten Tegal, Kabupaten Brebes, Kota Magelang, Kota Surakarta, Kota Salatiga, Kota Semarang, Kota Pekalongan, dan Kota Tegal.

\section{Perkembangan Penduduk Jawa Tengah Sebagai Faktor Penentu Perkembangan Kota Tabel 1. \\ Perkembangan Penduduk Jawa Tengah}

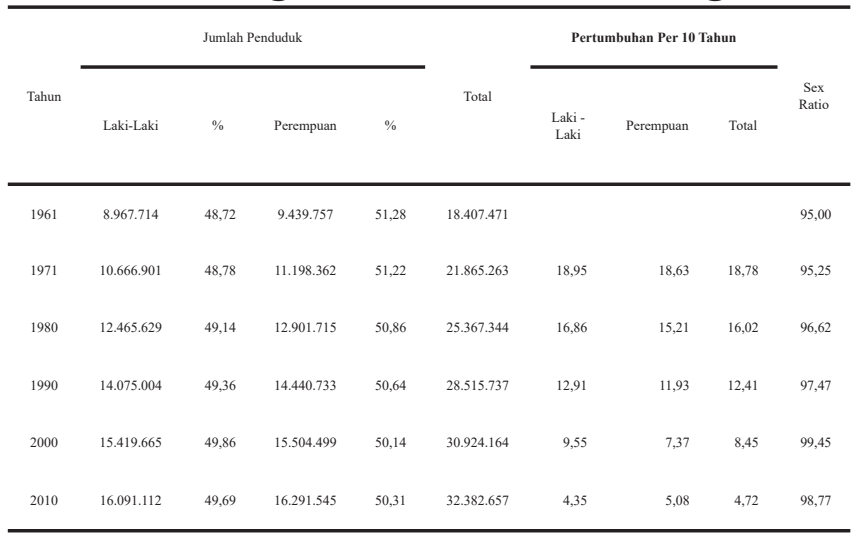

Sumber: Jawa Tengah Dalam Angka, berbagai tahun, diolah
Tabel 1 menunjukkan perkembangan penduduk Jawa Tengah dilihat berdasar tahun sensus penduduk. Selama tiga periode sensus telah terjadi pertumbuhan jumlah penduduk, yang menurun cukup signifikan. Sex Ratio cukup
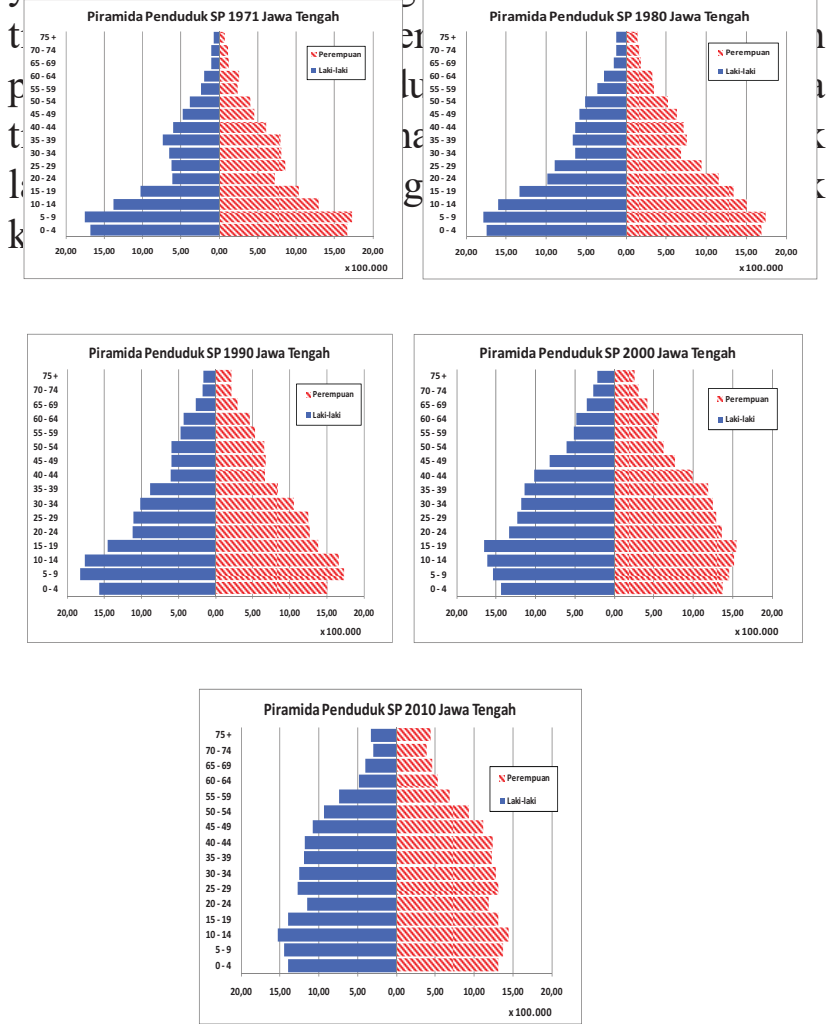

Sumber : Analisa Hasil Sensus Penduduk 2010 Berkaitan dengan KKB di Provinsi Jawa Tengah, BKKBN Jawa Tengah 2011.

\section{Gambar 2}

\section{Perkembangan Perubahan Struktur Penduduk Jawa Tengah}

Bentuk piramida penduduk dapat mencerminkan kondisi penduduk suatu wilayah. Provinsi Jawa Tengan tahun 1971 - 2010 dilihat dari perkembangan stuktur penduduknya, meunjukkan adanya perubahan - perubahan yang mendasar. Secara kasar terlihat bentuk piramida penduduk Jawa Tengah berkembang menuju bentuk stationer. Berdasar tipe piramida 
penduduk, tahun 1971, 1980 dan 1990 piramida berbentuk ekspansif yang berarti komposisi penduduk muda cenderung lebih banyak dari komposisi penduduk tua. Pada bentuk piramida ekspansif, angka kelahiran tinggi dan angka kematian tinggi. Hal ini salah satunya disebabkan karena usia pernikahan yang cenerung dini, fasilitas kesehatan yang kurang memadai dan gizi buruk.

Tahun 2000, bentuk piramida penduduk berubah menuju bentuk piramida stasioner. Piramida stasioner adalah bentuk piramida yang pada umumnya ditemukan di negara maju. Karakteristik dari piramida stasioner adalah angka kelahiran dan kematian rendah. Struktur penduduk yang seperti ini memunculkan implikasi pada persoalan kependudukan yang akan muncul, dikarenakan angka pertumbuhan relatif rendah, dan penduduk usia tua yang tinggi menyebabkan angka rasio ketergantungan akan semakin besar. Perubahan-perubahan ini memunculkan kebutuhan akan penanganan yang sesuai dan berimplikasi pada aktivitas-aktivitas pemerintah maupun masyarakat keseluruhan yang akan mempengaruhi kondisi kota tempat tinggalnya.

Secara sederhana, pengaruh penduduk terhadap perkembangan kota dapat digambarkan dalam skema 3.2.

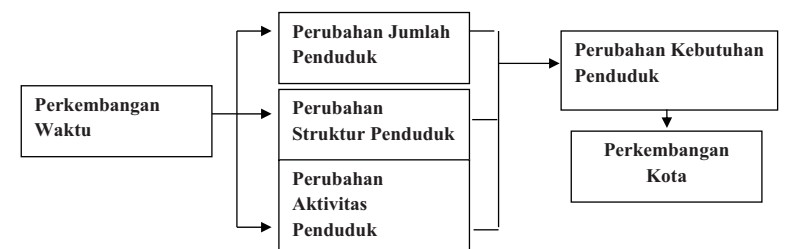

Gambar 3.

Konsep Pengaruh Perkembangan Waktu Terhadap Perkembangan Kota Melalui Variabel Penduduk

\section{Perubahan Hirarki Kota Provinsi Jawa Tengah}

Provinsi Jawa Tengah merupakan Provinsi yang cukup besar yang memiliki 35 kabupaten/ kota. Kabupaten/Kota tersebut memiliki karakteristiknya masing-masing namun tetap saling terkait dan saling mempengaruhi. Bila diukur berdasar besaran tertentu Kabupaten/ Kota di Jawa Tengah tersebut dapat disusun menjadi suatu hirarki perkotaan.

Perkembangan aktivitas penduduk, sistem transportasi dan tehnologi sejalan dengan perkembangan waktu dalam jangka panjang dapat menimbulkan suatu perubahan hirarki perkotaan. Hal ini juga disebabkan karena kabupaten/ kota yang berdekatan akan saling terhubung dan mempengaruhi, pernyataan ini logis bila mengingat kembali definisi kota.

Berkaitan dengan konteks ruang di dalam Tarigan (2006), kota merupakan satu sistem yang tidak berdiri sendiri, karena secara internal kota merupakan satu kesatuan sistem kegiatan fungsional di dalamnya, sementara secara eksternal, kota dipengaruhi oleh lingkungan sekitarnya. Kota ditinjau dari aspek fisik merupakan kawasan terbangun yang terletak saling berdekatan/ terkonsentrasi, yang meluas dari pusatnya hingga ke wilayah pinggiran, atau wilayah geografis yang didominasi oleh struktur binaan. Kota ditinjau dari aspek sosial merupakan konsentrasi penduduk yang membentuk suatu komunitas yang bertujuan untuk meningkatkan produktivitas melalui konsentrasi dan spesialisasi tenaga kerja. Kota ditinjau dari aspek ekonomi memiliki fungsi sebagai penghasil produksi barang dan jasa, untuk mendukung kehidupan penduduknya dan untuk keberlangsungan kota itu sendiri.

Berikut perubahan hirarki kota Jawa Tengah diukur dengan aspek jumlah penduduk kota. 


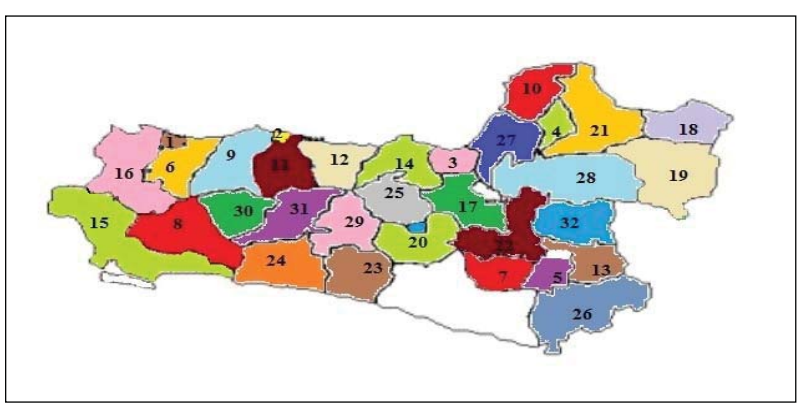

Sumber: Data BPS 1990, diolah

Gambar 4

Hirarki Penduduk Kabupaten Kota Jawa Tengah Tahun 1990

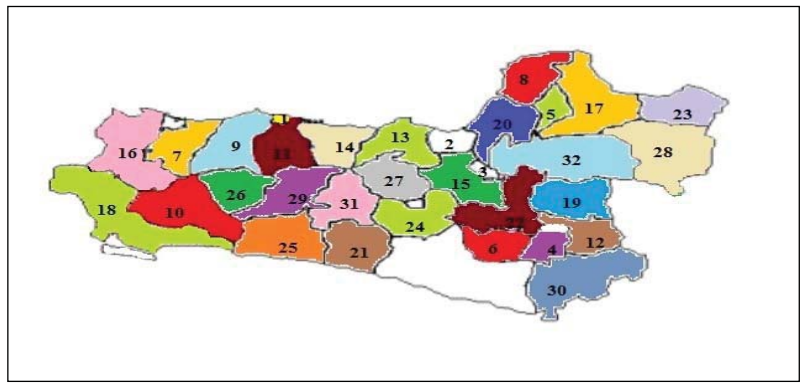

Sumber: Data BPS 2000, diolah

\section{Gambar 5}

Hirarki Penduduk Kabupaten Kota Jawa Tengah Tahun 2000

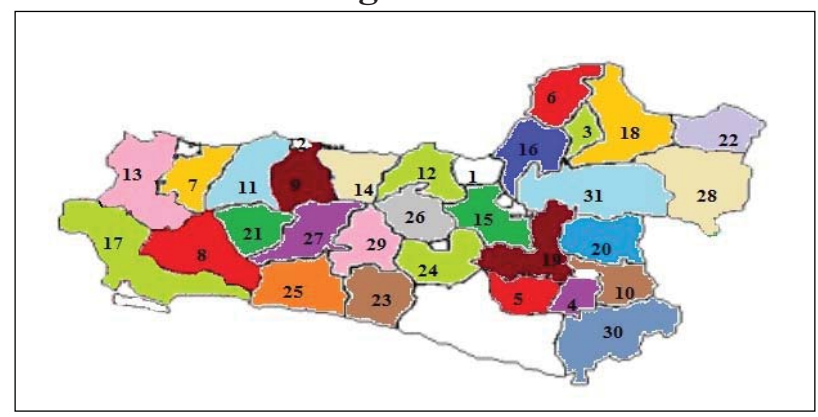

Sumber: Data BPS 2010, diolah

\section{Gambar 6}

\section{Hirarki Penduduk Kabupaten Kota Jawa Tengah Tahun 2010}

Gambar diatas menunjukkan perubahan hirarki kota yang terjadi pada kabupaten kota se Jawa Tengah mulai dari tahun 1990, 2000 dan 2010 dilihat berdasarkan rasio jumlah penduduk di perkotaan dan pedesaan dari ketiga tahun tersebut. Karena keterbatasan data yang diperoleh, maka ada beberapa kabupaten kota yang tidak tercantum pada gambar diatas (Kota Surakarta dan Kota Magelang). Dari perubahan hirarki pada tahun 1990 - 2010 terlihat bahwa pada awal pengambilan data yaitu tahun 1990, Kota Tegal menduduki peringkat pertama, dilanjutkan oleh Kota Pekalongan pada posisi kedua dan Kota Semarang pada posisi ketiga. Sedangkan pada tahun 2000, Posisi tertinggi diduduki oleh Kota Pekalongan yang diikuti oleh Kota Semarang pada posisi kedua dan Kota Salatiga pada posisi ketiga. Untuk tahun terbaru, yaitu tahun 2010, posisi hirarki atau peringkat kota tertinggi diduduki oleh Kota Semarang, yang mengalami pertumbuhan penduduk yang pesat, dan didikuti oleh Kota Pekalongan pada posisi kedua dan Kota Kudus pada posisi ketiga. Sedangkan untuk kabupaten kota yang lainnya pada umumnya mengalami pertumbuhan juga secara keseluruhan. Perubahan hirarki yang paling besar terjadi pada Kabupaten Sragen, pada tahun 1990 menempati posisi 32, tahun 2000 menjadi 19 dan tahun 2010 menjadi 20. Diikuti oleh Kabupaten Purbalingga $(30,26,21)$ dan Kabupaten Demak $(27,20,16)$. Dan untuk kota lainnya kenaikan dan penurunan peringkatnya tidak terlalu besar.

Saat ini Kota Semarang memang mengalami pertumbuhan yang sangat pesat pada hampir semua aspek. Keuntungan pertumbuhan tersebut didukung karena Kota Semarang merupakan jalur perlintasan yang berada tepat di tengah-tengah antara Jakarta dan Surabaya, sehingga dengan mengusung visi sebagai kota jasa, maka Kota Semarang mulai tumbuh dan berkembang dengan pesat. Selain jasa, industri di kota ini juga sangat pesat perkembangannya dari tahun ke tahun. Hal inilah yang menjadi daya tarik utama bagi penduduk yang masuk ke Kota Semarang untuk mencari pekerjaan, sehingga menyebabkan pertumbuhan penduduk di Kota Semarang sangat pesat dan menduduki peringkat pertama kota pada tahun 2010 . 


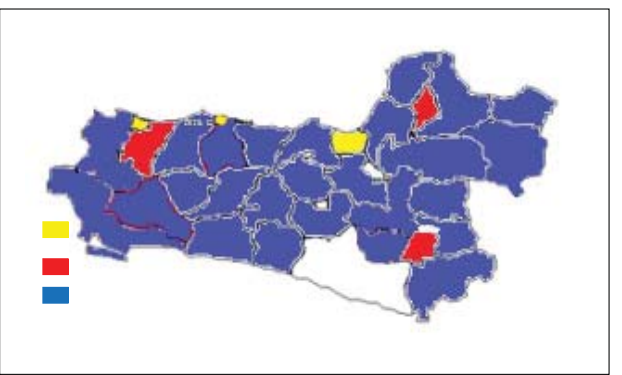

Orde $\mathrm{Ke}-1 \quad(98,28>\mathrm{X} \geq 68,37)$

Orde Ke $-2(68,37>X \geq 38,45)$

Orde $\mathrm{Ke}-3(38,45>\mathrm{X} \geq 8,54)$

Sumber : Data BPS 1990, diolah

\section{Gambar 7}

\section{Orde Kota Kabupaten Kota Jawa Tengah} Tahun 1990

Dari 35 kabupaten kota di Jawa Tengah, rasio jumlah penduduknya dibagi menjadi 3 Orde dengan nilai setiap orde seperti pada keterangan diatas. Pada tahun 1990 Orde kota 1 hanya terdiri dari 3 kota, yaitu Kota Semarang, Kota Pekalongan dan Kota Tegal, artinya ketiga kota tersebut memiliki rasio penduduk yang paling tinggi diantara lainnya. Sedangkan orde kote ke -2 ada 3 kota, yaitu Kudus, Kabupaten Tegal dan Sukoharjo. Kabupaten kota yang lainnya masuk dalam orde ke-3.

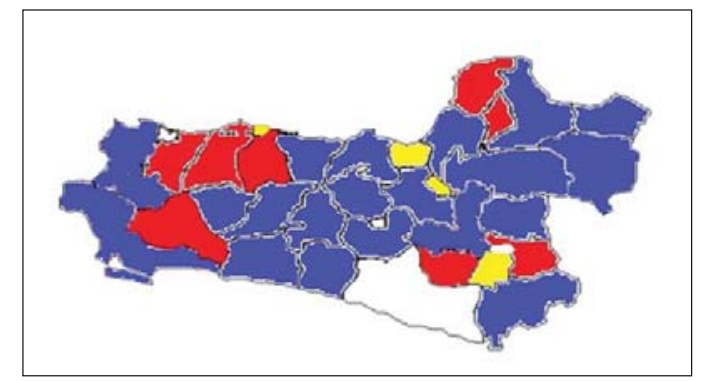

- Orde Ke $-1(97,82>X \geq 70,00)$

- Orde Ke $-2(70,00>X \geq 42,17)$

- Orde Ke $-3(42,17>X \geq 14,34)$

Sumber: Data BPS 2000, diolah

Gambar 8

Orde Kota Kabupaten Kota

Jawa Tengah Tahun 2000
Pada tahun 2000 Orde kota satu terdiri dari empat kota, yaitu Kota Semarang, Kota Pekalongan, Kota Salatiga dan Sukoharjo, artinya keempat kota tersebut memiliki rasio penduduk yang paling tinggi diantara lainnya. Sedangkan orde kote ke dua ada delapan kota, yaitu Banyumas, Klaten, Karanganyar, Kudus, Pekalongan, Pemalang, Jepara dan Tegal. Kabupaten kota yang lainnya masuk dalam orde ketiga.

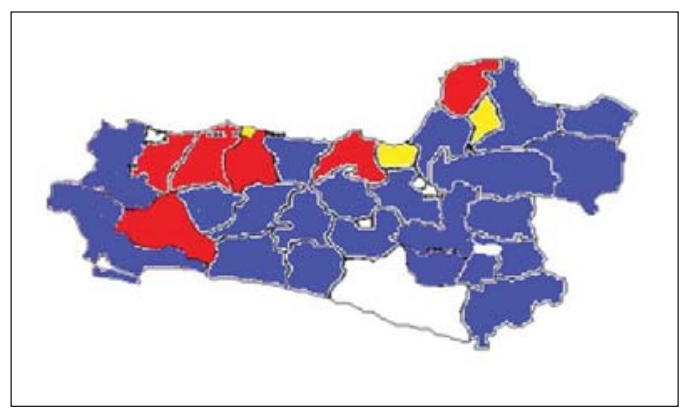

Orde Ke $-1(97,72>X \geq 70,61)$

- Orde Ke $-2(70,61>X \geq 43,50)$

- Orde Ke $-3(43,50>X \geq 16,39)$

Sumber: Data BPS 2010, diolah

\section{Gambar 9 \\ Orde Kota Kabupaten Kota Jawa Tengah Tahun 2010}

Orde kota pada ketiga gambar diatas mencerminkan orde kota dalam kurun waktu 20 tahun, yaitu tahun 1990, 2000 dan 2010. Sebagian besar kabupaten kota di Jawa Tengah menempati Orde Kota ke -3 atau tingkatan yang paling rendah.

Pada tahun 2010 Orde kota 1 terdiri dari 3 kota, yaitu Kota Semarang, Kota Pekalongan dan Kudus, artinya ketiga kota tersebut memiliki rasio penduduk yang paling tinggi diantara lainnya. Sedangkan orde kota ke- 2 ada 6 kota,yaitu Jepara Pemalang, Tegal, Pekalongan, Banyumas dan Kendal. Kabupaten kota yang lainnya masuk dalam orde ke-3. 
Kota semarang saat ini mengalami pertumbuhan yang pesat, sehingga menurut penelitian Ir. Saratri Wilonoyudho, M.Si., Kota Semarang telah mengalami deindustrialisasi. Akibat dari dampak urbanisasi berlebih, dimana tingkat urbanisasi tidak diimbangi tingkat industrialisasi. Bahkan, kepadatan penduduk kota semarang juga telah menyebabkan daya dukung lingkungan dan daya tampung sosial menjadi rendah. Saratri menegaskan di kota semarang telah terjadi kecenderungan urbaniasasi dengan pola menyebar yang ditandai pertumbuhan penduduk perkotaan yang tinggi di kabupaten-kabupaten di sekitar kota semarang. Selain itu, berdampak pada kerusakan lingkungan, kemacetan lalu lintas dan tingginya angka kejahatan, peran sektor industri dan pertanian di Kota Semarang cenderung menurun, sebaliknya sektor informal justru semakin meningkat. Urbanisasi di Kota Semarang justru memunculkan gejala involusi kota yakni terus meningkatnya jumlah pekerja di sektor informal dengan produtivitas rendah, sebagaimana ditunjukkan pada PDRB (produk domestik regional bruto) sektor industri di kota semarang yang relatif kecil dibandingkan PDRB di sektor jasa atau perdagangan (Pikiran Rakyat, 21 November 2011). Berdasarkan alasan tersebut maka Kota Semarang dapat dikatakan hampir mencapai optimum, apabila dilihat dari pertumbuhan penduduk dan infrastruktur yang tersedia. Tetapi dengan kebijakan-kebijakan yang nantinya diharapkan lebih bijaksana untuk membangun kota dan menambah infrastruktur yang lebih baik agar pelayanannya dapat menjangkau seluruh masyarakat maka Kota Semarang dapat dikatakan belum mencapai optimum. Apabila keadaan sekarang dibiarkan tanpa adanya kebijakan-kebijakan mendukung dari pemerintah maka Kota Semarang akan menuju pada over optimum seperti Jakarta dan kota besar paa umumnya.

\section{KESIMPULAN DAN SARAN}

Penduduk merupakan salah satu sumber daya yang mempunyai peran penting dalam pembangunan yang ingin dicapai suatu wilayah. Perkembangan jumlah penduduk mengakibatkan meningkatnya aktivitas penduduk, sistem transportasi dan teknologi sejalan dengan perkembangan waktu dalam jangka panjang dapat menimbulkan suatu perubahan hirarki perkotaan atau peringkat yang diduduki oleh suatu kota. Hal ini juga disebabkan karena kota/ kabupaten yang berdekatan akan saling terhubung dan mempengaruhi, pernyataan ini logis bila mengingat kembali definisi kota.

Perubahan hirarki perkotaan yang terjadi pada tahun 1990-2010 pada kabupaten kota se Jawa Tengah, telah memperlihatkan bahwa posisi hirarki yang paling tinggi saat ini diduduki oleh Kota Semarang, hal ini seiring dengan semakin pesatnya perkembangan kota sehingga menjadi daya tarik yang cukup besar bagi penduduk wilayah sekitar untuk berpindah ke Kota Semarang yang pada akhirnya akan sangat mempengaruhi peningkatan jumlah penduduk Kota Semarang yang semakin besar.

\section{DAFTAR PUSTAKA}

Ambardi, Urbanus M dan Socia Prihawantoro, 2002. Pengembangan Wilayah dan Otonomi Daerah. Pusat pengkajian kebijakan pengembangan wilayah (P2KTPW- BPPT). Jakarta.

Analisa Hasil Sensus Penduduk 2010 Berkaitan dengan KKB di Provinsi Jawa Tengah, BKKBN Jawa Tengah 2011.

Badan Pusat Statistik, Jateng Dalam Angka, Berbagai Tahun,

Badan Pusat Statistik, Sensus Penduduk, Berbagai Tahun

Bintarto, R., 1977, Pengantar Geografi Kota, U.P. Spring Yogyakarta. 
Harry W. Richardson, Dasar - dasar Ilmu Ekonomi Regional, diterjemahkan oleh Paul Sitohang.2004

Kanemoto, Yoshitsugu, 1996, Agglomeration Economies and a Test for Optimal City Sizes in Japan

Majalah geografi Indonesia, Th 4-6 No 6-9, 1992, Su Ritohardoyo dan Rafeal Murtomo

Pikiran Rakyat, Waspadai Involusi Kota Akibat Urbanisasi. 21 November 2011

Rondinelli, Dennis A \& Cheema, G. Shabbir, 1983. Decentralization and Development Policy Implementation in Developing Countries. Beverly Hills London: Sage Publications.
Rusmansyah, TESIS, Arahan Pengembangan Kawasan Barat Kabupaten Bangka, 2006

Sukirno, Sadono, 1985, Ekonomi Pembangunan: Proses, Masalah, dan Kebijaksanaan, LPFE-UI, Jakarta.

Tarigan, Robinson. 2004. Perencanaan Pembangunan Wilayah. Jakarta: PT Bumi Aksara

Tarigan, Robinson. 2006. Ekonomi Regional: Teori dan Aplikasi (Edisi Revisi). Bumi Aksara. Jakarta.

Zipf, G.K. 1946, The $\mathrm{P}_{1}, \mathrm{P}_{2} / \mathrm{D}$ hypothesis on the intercity movement of person, American Sociological Review, vol. 11, halaman 67-86. 